\title{
Analysis of Rasasindura Employing Namburi Phased Spot Test (NPST)
}

\author{
Patil Rohan, Veena BK*, Dindore Pallavi and Skandhan KP \\ Department of Rasashastra and Bhaishajya kalpana, KAHER'S Shri B.M Kankanawadi \\ Ayurveda Mahavidyalaya, A Constituent unit of KLE Academy of Higher Education and \\ Research, Belagavi, India
}

\section{Research Article}

Volume 2 Issue 5

Received Date: June 21, 2018

Published Date: July 06, 2018

Asistant Professor Department of Rasashastra and Bhaishajya kalpana, Late Kedari Redekar Ayurvedic Mahavidyalaya Gadhinglaj, India

*Corresponding Author: Dr. Veena.B.Kupati, Assistant professor, Department Rasashastra and Bhaishajya kalpana, KAHER Shri B. M Kankanawadi Ayurveda Mahavidyalaya Belagavi - 590 003, Tel no: 8867674853; Email: veenakupati@gmail.com

\section{Abstract}

Rasasindura is commonly used in Kupipakwa Rasayana, a herbo mineral preparation. This is prescribed for different diseased condition including Prameha (Diabetes mellitus), Kushtha (Leprosy), Pradara (Menorrhagea) and Jwara (Fever). Before introducing to the market a product has to undergo a systemic analysis as a primary step. In this study we selected Namburi Phased Spot Test (NPST) analysis as a qualitative step. Rasasindura underwent NPST analysis. The result observed here was brick red solid spot with dark brown periphery proving Rasasinduratallies with that of standard.

Keywords: Rasasindura; NPST analysis; Brick red; Phases

\section{Introduction}

Rasasindura is a sublime product of a mixture of 1 part of Navasadara and 8 parts of Kajjali [equal quantity of Parada (Mercury) and Gandhaka (Sulphur)] [1,2]. This is used for therapeutical purpose in many conditions like Prameha (Diabetes mellitus), Kushtha(Leprosy), Pradara (Menorrhagea), Jwara (Fever), Shwasa (Hiccough) and Bhagandara (Fistulo in ano) [3]. It is also used in different formulations like Kampavatari rasa and Ekangaveera rasa [4]. The purity of any preparation is important before prescribing it to the patients. Methods are available to verify the purity of a preparation. In this study an attempt is made to understand the quality of Rasasindura

\section{Materials and Methods}

Procedure: Rasasindura $(0.25 \mathrm{gm})$ was taken into centrifuge test tube and to which drop by drop a freshly prepared $0.5 \mathrm{ml}$ aqua regia was added. Solution was kept undisturbed for about 30 minutes for its reaction to be taken place. Then it was heated gently on a spirit lamp for about a minute. The solution was shaken occasionally during $48 \mathrm{hrs}$ and allowed to react. Afterwards one drop of sample was put on the $10 \%$ Pot. Iodide paper prepared by using Whatman filter paper No 1 . Single sample was used for the analysis of Rasasindura [5,6]. 


\section{Journal of Natural \& Ayurvedic Medicine}

\section{Observation and Results}

Colour changes during a study were observed in three different phases, $1^{\text {st }}$ phase: 0 to $5 \mathrm{~min}, 2^{\text {nd }}$ phase: $05 \mathrm{~min}$ to $20 \mathrm{~min}$ and $3^{\text {rd }}$ phase: $20 \mathrm{~min}$ to 72 hours. At the end of third phase reaction showed Brick red solid spot with dark brown periphery.

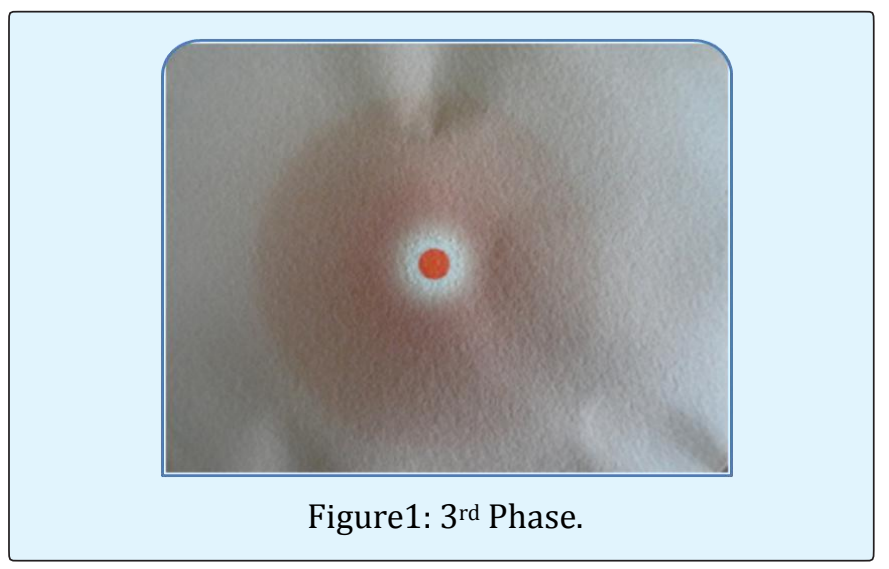

\begin{tabular}{|c|c|c|c|c|}
\hline Sample & Solution & Paper & \multicolumn{2}{|c|}{ Observation } \\
\hline \multirow{2}{*}{ Rasasindura } & $\begin{array}{c}\text { Rasasindura } \\
+0.5 \mathrm{ml} \\
\text { Aqua regia }\end{array}$ & $10 \% \mathrm{KI}$ & Phase 1 & $\begin{array}{c}\text { Brick red solid } \\
\text { spot }\end{array}$ \\
\cline { 3 - 5 } & & $\begin{array}{c}\text { Brick red solid } \\
\text { pot with brown } \\
\text { periphery } \\
\text { slowly fades to } \\
\text { away }\end{array}$ \\
\cline { 3 - 5 } & & Phase 3 3 & $\begin{array}{c}\text { Brick red solid } \\
\text { spot with dark } \\
\text { brown } \\
\text { periphery }\end{array}$ \\
\hline
\end{tabular}

Table 1: Results of NPST analysis.

\section{Discussion}

Rasaushadhi's is one of the medicaments in treating several diseases due to its quick action and use in smaller doses. Rasasindura is one among them which is commonly used drug in a day today practice. Before made available in the market drugs have to undergo several qualitative tests. In this study we selected NPST analysis as a primary test to check its potentiality. NPST is a qualitative test used to identify the Bhasma or Sindura.
This is based on chemical reaction between chemical reacting paper and solution of drug prepared in different reagents. The Central Council for Research in Ayurvedic Science (CCRAS) accepted this is one of the basic steps for quality control of Rasaushadhi. NPST analysis is based on colour which is observed on three different phases at three different intervals. After the addition of bhasma into reagents effervescence started and later it got settled. The solution got cleared after heating and colour of residue was red. The solution was slightly yellowish in colour due to the reagent used in preparation of solution. The reacting papers were slightly brownish in colour, after putting a drop of clear solution brick red colour was developed within a fraction of time then slowly fades to brown, similar observation was reported earlier [7].

\section{Conclusion}

In the present study Rasasindura showed positive result in comparison with standards.

\section{References}

1. Sharma PS (2000) Rasatarangini. Varanasi, MotilalaBanarasidas publication. pp: 138.

2. Gokarn RA, Rajput DS, Patgiri B (2012) Pharmaceutical standardization of Samaguna Bali JaritaRasasindura prepared by conventional and modified method. Ancient Sci Life 31(3): 123-128.

3. Sharma PS (2000) Rasatarangini. Varanasi, MotilalaBanarasidas publication pp: 143-145.

4. Dattaram PSL (1888) Ras Raj Sundar. Mathura, Kamala Prakash. pp: 549-550.

5. CCRAS (2010) Ministry Of Health And FW Government Of India, New Delhi, Application of Standardized Namburi Phased Spot Test in identification of Bhasma and Sindura Preparations of Ayurveda. pp: 53.

6. Nambhuri RH Application of StandarsisedNamburi Phased Spot Test. Project work submitted to CCRAS, New Delhi.

7. Veena BK, Jadar PG (2014) Namburi phased spot test analysis of Rasasindura. Int j Sci Resea 3(11): 19-20.

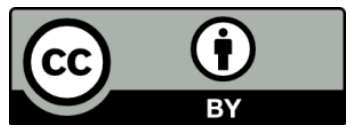

